\title{
Adiponectin effects on human breast cancer cells are dependent on 17- $\beta$ estradiol
}

\author{
GEORG H. PFEILER ${ }^{1}$, CHRISTA BUECHLER ${ }^{2}$, MARKUS NEUMEIER ${ }^{2}$, \\ ANDREAS SCHÄFFLER ${ }^{2}$, GERD SCHMITZ ${ }^{3}$, OLAF ORTMANN ${ }^{1}$ and OLIVER TREECK ${ }^{1}$ \\ ${ }^{1}$ Department of Obstetrics and Gynecology, University of Regensburg; ${ }^{2}$ Department of Internal \\ Medicine I, University Hospital of Regensburg; ${ }^{3}$ Institute of Clinical Chemistry and \\ Laboratory Medicine, University of Regensburg, D-93042 Regensburg, Germany
}

Received August 28, 2007; Accepted October 19, 2007

\begin{abstract}
Adiponectin, an adipocyte-derived serum protein, is known to positively affect the glucose and lipid metabolism and these effects are mediated by its receptors, AdipoR 1 and R2. Serum adiponectin levels are inversely associated with breast cancer risk, but the molecular mechanisms underlying this association are not fully elucidated. Thus, the purpose of this study was to investigate the influence of adiponectin on breast cancer cells in vitro. We were able to demonstrate the expression of AdipoR1 and R2 in MCF-7, MDA-MB-231 and SK-BR-3 breast cancer cells on the mRNA level. Furthermore, the AdipoR1 protein could be detected by immunoblot analysis. In MCF-7 breast cancer cells, the expression of AdipoR1 significantly declined after stimulation with 17- $\beta$ estradiol, whereas the cyclin A2 expression significantly increased. Both effects were inhibited by the addition of adiponectin. Treatment with different concentrations of adiponectin in steroid-hormone-free medium did not affect cell proliferation or apoptosis. In contrast, after the addition of $17-\beta$ estradiol, adiponectin slightly decreased the growth of the MDA-MB-231 and SK-BR3 cells but increased proliferation of the hormone-dependent MCF-7 breast cancer cells. Adiponectin also triggered cellular apoptosis in MDA-MB-231 breast cancer cells in the presence of $17-\beta$ estradiol. These findings suggest that a cross-talk between adiponectin and estrogen receptor signaling exists in breast cancer cells and that adiponectin effects on the growth and apoptosis of breast cancer cells in vitro are dependent on the presence of 17- $\beta$ estradiol.
\end{abstract}

Correspondence to: Dr Oliver Treeck, Department of Obstetrics and Gynecology, University of Regensburg, Landshuter Str. 65, D-93042 Regensburg, Germany

E-mail: otreeck@caritasstjosef.de

Key words: adiponectin, breast cancer cell lines, 17-ß estradiol, apoptosis

\section{Introduction}

It has become increasingly clear that metabolic disorders are able to affect breast cancer risk. It is estimated that up to $50 \%$ of postmenopausal breast cancer deaths in the USA can be attributed to obesity $(1,2)$. One explanation for this association, are elevated circulating estrogen levels resulting from peripheral aromatization of androgens in the adipose tissue in obese postmenopausal women (3). Several studies have demonstrated the association of body mass index (BMI) and serum estrogen levels as well as the association of serum estrogen levels with breast cancer risk $(4,5)$. A strong association of obesity with insulin resistance, characterized by hyperinsulinemia, has also been documented $(6,7)$. Increased serum insulin and free IGF I, which stimulate the proliferation of breast cancer cells in vitro, are thought to play an important role in the development of breast cancer $(8,9)$.

However, the fact that BMI serves as a risk factor for breast cancer being independent of serum estrogen and insulin levels indicates that an increase of these hormones is not the sole mechanism through which BMI affects breast cancer risk. The adipose tissue does not simply store excess energy, but also acts as an endocrine organ that secretes a variety of proteins in the blood. These include leptin, tumor necrosis factor (TNF)- $\alpha$, IL-6, adipsin, resistin and adiponectin and are collectively known as adipocytokines (10). Adiponectin was independently characterized in 1995 and 1996 by four groups using different methods. Thus, its alternative names are: apM1 (adipose most abundant gene transcript 1), Acrp30 (adipocyte complement-related protein of $30 \mathrm{kDa}$ ), adipoQ and GBP28 (gelatin-binding protein of $28 \mathrm{kDa}$ ) (11-14). Adiponectin receptors have been identified as mediating the effects of adiponectin and were found in nearly any cell or tissue investigated thus far (15).

A strong and consistent inverse association between adiponectin and both obesity and insulin resistance, has been established (16). The administration of recombinant adiponectin to rodents increases the glucose uptake and fat oxidation in muscle, reduces fatty acid uptake and hepatic glucose production in the liver and improves whole-body insulin resistance (17). Furthermore, it has been shown that adiponectin levels decrease in premenopausal women with 
endometrial carcinoma, a malignancy closely associated with obesity and insulin resistance (18). Miyoshi et al reported that serum adiponectin levels are inversely associated with breast cancer risk in pre- and postmenopausal women. They postulated that the low serum adiponectin levels can serve as a significant risk factor for breast cancer, being independent of the classical epidemiological risk factors described so far (19). Mantzoros et al found a significant inverse association of adiponectin and postmenopausal breast cancer, but not premenopausal breast cancer (20).

The mechanisms through which adiponectin modulates breast cancer risk are currently under investigation. By increasing insulin sensitivity and thereby decreasing serum insulin and free IGF, adiponectin could indirectly lower breast cancer risk. There is even evidence that adiponectin influences estrogen levels and thereby breast cancer risk (21). Furthermore, the direct antitumoral effects of adiponectin, namely the growth inhibition of myelomonocytic progenitors which was at least partly mediated by the induction of apoptosis, were reported $(22,23)$. Diudonne et al were able to demonstrate that adiponectin inhibits cell proliferation and increases apoptosis of the MCF-7 breast cancer cells, perhaps through AMPK phosphorylation and MAPK pathway inhibition (24).

Since adiponectin may influence estrogen levels and there seems to be a different effect of adiponectin on the breast cancer risk of pre- and postmenopausal women, respectively, it is tempting to speculate that a cross-talk between adiponectin signaling and estrogen receptor pathways may exist in breast cancer cells. In this study, we therefore examined the effects of adiponectin in the presence or absence of 17- $\beta$ estradiol on human breast cancer cells.

\section{Materials and methods}

Materials. Phenol red-free DMEM culture medium was obtained from Invitrogen (Karlsruhe, Germany), FCS was purchased from PAA (Pasching, Austria) and 17- $\beta$ estradiol, staurosporine and serum replacement 2 (SR2) were ordered from Sigma (Deisenhofen, Germany). The MCF-7, MDAMB-231 and SK-BR-3 breast cancer cells were obtained from The American Type Culture Collection (Manassas, USA). M-MLV-P reverse transcriptase, Cell Titer Blue kit, CaspaseGlo 3 and 7 kit and ImProm-II ${ }^{\mathrm{TM}}$ reverse transcriptase were purchased from Promega (Mannheim, Germany). The RNeasy mini kit, RNase-free DNase set and Quantitect Sybr-Green PCR kit were obtained from Qiagen (Hilden, Germany). PCR primers were synthesized by Metabion (Planegg-Martinsried, Germany). Full-length adiponectin was expressed in insect H5 cells as described (23). AdipoR1 antibody was generated as already published (27).

Cell viability assay. The MCF-7, MDA-MB-231 and SK-BR-3 breast cancer cells were maintained in a phenol red-free DMEM/F12 medium supplemented with $10 \%$ FCS or $1 \mathrm{x}$ serum replacement (SR2). Cells were cultured with $5 \% \mathrm{CO}_{2}$ at $37^{\circ} \mathrm{C}$ in a humidified incubator. For cell viability assay, cells were seeded in 96-well plates in triplicate (1000 cells/well), and were treated with adiponectin $(1-15 \mu \mathrm{g} / \mathrm{ml})$ or $17-\beta$ estradiol $(1 \mathrm{nM})$ for up to 5 days. After that period, the relative numbers of viable cells were measured in comparison to the untreated control and the solvent control using fluorimetrical and resazurin-based Cell Titer Blue assay (Promega) according to the manufacturer's instructions at $560_{\mathrm{Ex}} / 590_{\mathrm{Em}} \mathrm{nm}$ in a Victor 3 multilabel counter (PerkinElmer, Germany). Cell growth was expressed as a percentage of day 0 or percentage of the untreated medium control. A statistical analysis of the data was performed by one-way ANOVA using Prism 2.0 Software (Graph pad, San Diego, USA), with statistical significance accepted at $\mathrm{p}<0.05$.

Apoptosis assays. The human breast cancer cells, cultured in DMEM supplemented with 1x serum replacement 2 (SR2, Sigma), were seeded in 96-well plates (5000 cells/well) and treated with $1 \mathrm{nM} 17-\beta$ estradiol alone or in combination with adiponectin. After 6 and $24 \mathrm{~h}$ of treatment, cellular apoptosis was determined by measurement of the caspase 3 and 7 activity by means of the luminometric Caspase-Glo 3 and 7 assay (Promega) according to the manufacturer's protocol using a Victor 3 multilabel counter (PerkinElmer). Additionally, apoptosis was measured by means of the Annexin-V-Fluos staining kit (Roche, Germany). The cells were treated with Annexin $\mathrm{V}$ and propidium iodide (PI) according to the manufacturer's protocol and the apoptotic cells exhibiting a positive green Annexin V fluorescence but no red PI staining were counted. Cellular apoptosis was expressed as a percentage of the untreated control cells. A statistical analysis of the data was performed by one-way ANOVA using Prism 2.0 Software (Graph pad), with statistical significance accepted at $\mathrm{p}<0.05$.

Reverse transcription and PCR. Total RNA from the employed human breast cancer cells was isolated by means of the RNeasy kit (Qiagen) according to the manufacturer's instructions. From $1 \mu \mathrm{g}$ total RNA, cDNA was synthesized using $100 \mathrm{U}$ M-MLV-P reverse transcriptase (Promega), $2.5 \mathrm{mM}$ dNTP mixture and $50 \mathrm{pM}$ random primers (Invitrogen). To detect AdipoR1 and R2 mRNA by a standard RT-PCR, $2 \mu 1$ of cDNA was amplified in a reaction mix of $1 \mathrm{U}$ platinum polymerase (Invitrogen), $20 \mathrm{pmol}$ of each primer, 1X PCR-buffer, $1.5 \mathrm{mM} \mathrm{MgCl}_{2}$ and $2.5 \mathrm{mM}$ of each dNTP. The cDNA was amplified in 35 cycles $\left(1\right.$ cycle $=1$ min at $94^{\circ} \mathrm{C}$ melting, $2 \mathrm{~min}$ at $56^{\circ} \mathrm{C}$ annealing and $3 \mathrm{~min}$ at $72^{\circ} \mathrm{C}$ extension).

For the real-time PCR detection of AdipoR1, cyclin A2 and $\mathrm{D} 1$ and $\mathrm{ER} \alpha$ (intron-spanning primer sequences in Table I), $2 \mu 1$ cDNA were amplified using the Quantitect Sybr-Green PCR kit (Qiagen) and the LightCyler PCR device (Roche Diagnostics, Mannheim, Germany). The PCR program was $95^{\circ} \mathrm{C}$ for $15 \mathrm{~min}$, followed by $35 \mathrm{PCR}$ cycles $\left(95^{\circ} \mathrm{C}\right.$ for $10 \mathrm{sec}$, $56^{\circ} \mathrm{C}$ for $30 \mathrm{sec}$ and $72^{\circ} \mathrm{C}$ for $30 \mathrm{sec}$ ) and a final extension for 5 min at $72^{\circ} \mathrm{C}$, followed by a standard melting curve analysis. In all RT-PCR experiments, a 190 bp B-actin fragment was amplified as a reference. After performing dilution experiments with a sample cDNA over a 100 -fold range confirming the PCR efficiencies of all primer pairs to be approximately equal (25), data were analyzed using the comparative $\Delta \Delta \mathrm{C}_{\mathrm{T}}$ method (26) to calculate the difference between the threshold cycle $\left(\mathrm{C}_{\mathrm{T}}\right)$ values of the target and reference gene of each sample and then compare the resulting $\Delta \mathrm{C}_{\mathrm{T}}$ values between different samples. In these experiments, mRNA not subjected 
Table I. PCR primers used in this study.

\begin{tabular}{ll}
\hline AdipoR1 & 5'-GGG GAA TTC TCT TCC CAC AAA GGA TCT GTG GTG-3' \\
& 5'-GGG CTG CAG TTA AGT TTC TGT ATG AAT GCG GAA GAT-3' \\
AdipoR2 & 5'-GGG GAA TTC AAC GAG CCA ACA GAA AAC CGA TTG-3' \\
ER $\alpha$ & 5'-GGG CTG CAG CTA AAT GTT GCC TGT TTC TGT GTG TAT-3' \\
& 5'-TGA TGA AAG GTG GGA TAC GA-3' \\
Cyclin D1 & 5'-AAG GTT GGC AGC TCT CAT GT-3' \\
& 5'-CTG GAG GTC TGC GAG GAA-3' \\
Cyclin A2 & 5'-GGG GAT GGT CTC CTT CAT CT-3' \\
& 5'-CTG CTG CTA TGC TGT TAG CC-3' \\
B-actin & 5'-TGT TGG AGC AGC TAA GTC AAA A-3' \\
& 5'-CTG TGG CAT CCA CGA AAC TA-3' \\
\hline
\end{tabular}

to reverse transcription was used as a negative control to distinguish cDNA and the vector or genomic DNA amplification.

\section{Results}

The expression of the adiponectin receptors AdipoR1 and R2 in the MCF-7, MDA-MB-231 and SK-BR-3 breast cancer cells was analyzed by RT-PCR. mRNA for AdipoR1 was detected in all the breast cancer cell lines tested, whereas AdipoR2 was detected in the MCF-7 and MDA-MB-231 breast cancer cells, but not in the SK-BR-3 cells (Fig. 1a). By using an AdipoR1 antibody for immunoblotting, we confirmed the AdipoR1 expression in these cell lines at the protein level, though the MDA-MB-231 cells exhibited a significantly weaker AdipoR1 protein (Fig. 1b).

The employed human breast cancer cell lines were incubated with sub-, supra- and physiological concentrations of adiponectin (1-15 $\mu \mathrm{g} / \mathrm{ml})$ in a serum-free medium and in a medium supplemented with $10 \%$ FCS. Cell proliferation and apoptosis were examined. After 5 days of treatment, we could not observe any effect of adiponectin on the breast cancer cell proliferation in the serum-free medium (Fig. 2a) or the medium supplemented with FCS (data not shown). Neither the treatment time nor the concentration of adiponectin had any effect on the proliferation of the MCF-7, MDA-MB-231 and SK-BR-3 breast cancer cells. Furthermore, no effect of adiponectin on breast cancer cell apoptosis was observed (Fig. 2b).

To examine whether the addition of $17-\beta$ estradiol (E2) may modulate the cellular response to adiponectin, the effects of $\mathrm{E} 2$ on the AdipoR1 and R2 expression were investigated. MCF-7, MDA-MB-231 and SK-BR-3 breast cancer cells were treated with $3 \mathrm{nM}$ E2 and subsequently the adiponectin receptor expression was quantified by RT-PCR. Notably, treatment with E2 for $24 \mathrm{~h}$ significantly decreased the AdipoR1 expression in the MCF-7 breast cancer cells (Fig. 3a). This effect was completely reversible by adding adiponectin. There was no influence of E2 on the AdipoR2 expression in the MCF-7 cells (data not shown). The expression of a)

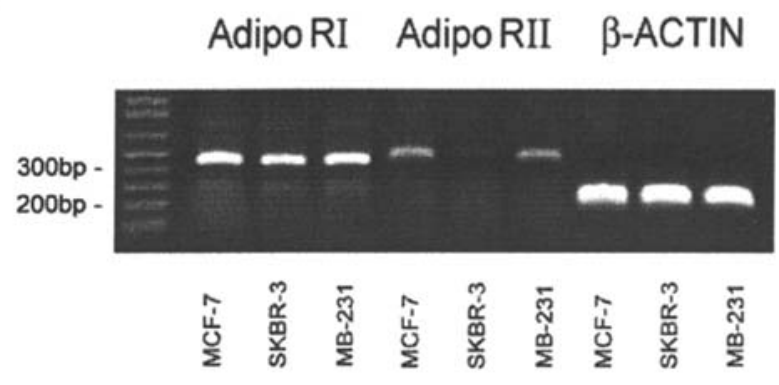

b)

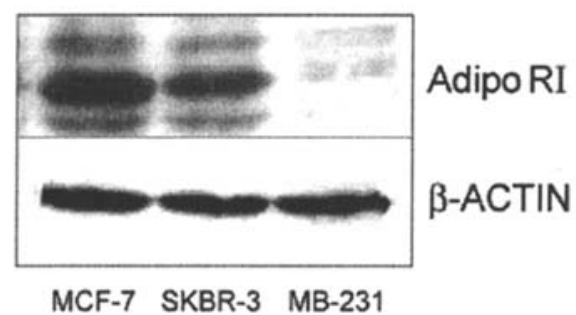

Figure 1. Detection of adiponectin receptors in human breast cancer cells. (a) AdipoR1 and R2 mRNA were detected by RT-PCR and the B-actin is shown as a positive control. (b) AdipoR1 protein was detected by Western blot analysis using an AdipoR1 antibody and the B-actin was analyzed as a loading control.

adiponectin receptors in the MDA-MB-231 and SK-BR-3 breast cancer cells was not influenced by E2.

Treatment with E2 alone or in combination with adiponectin was performed to examine cell proliferation and apoptosis. After treatment with E2 alone, we observed a significantly increased proliferation of the MCF-7 cells, as expected, whereas the growth of the MDA-MB-231 and SK-BR breast cancer cells was not affected by this steroid hormone. A combination of E2 with adiponectin further increased proliferation of the MCF-7 cells after 3 and 4 days of treatment, whereas the proliferation of MDA-MB-231 and 
a)

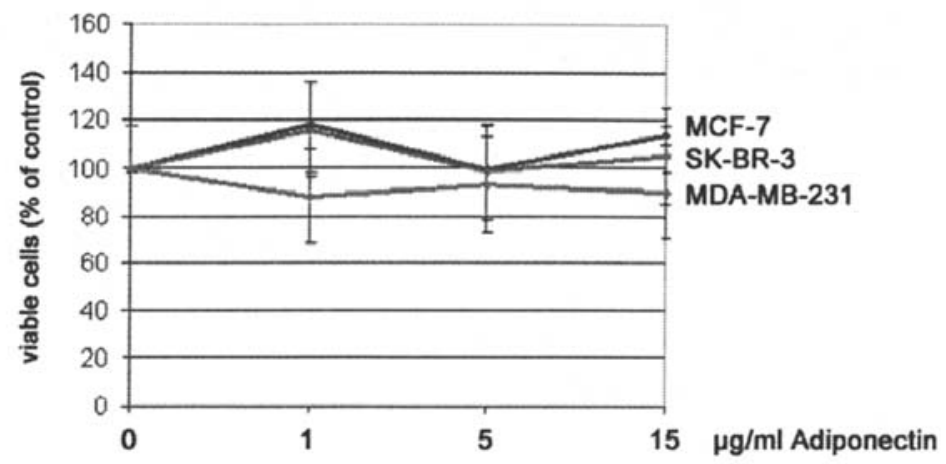

b)

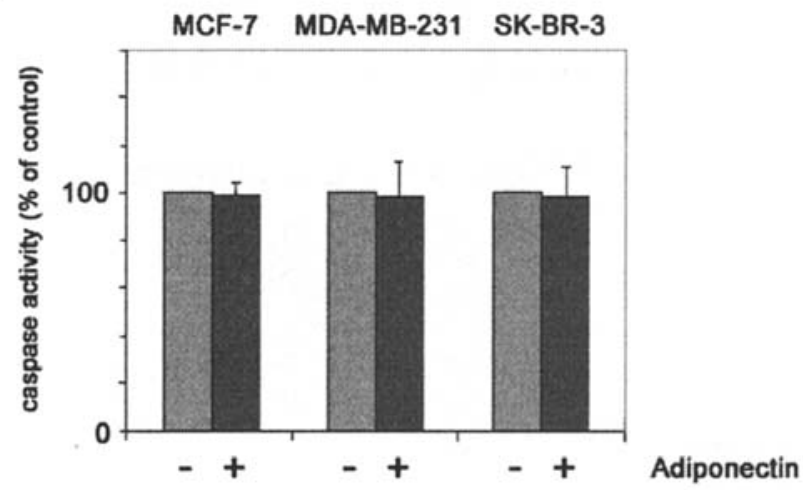

Figure 2. The effects of adiponectin on human breast cancer cells in a steroid-hormone-free medium. (a) Human breast cancer cells were treated with the indicated concentrations of adiponectin for 5 days and the relative cell numbers were assessed by the CTB assay. (b) Cells were treated with $15 \mu \mathrm{g} / \mathrm{ml}$ adiponectin and caspase 3 and 7 activation was detected after $6 \mathrm{~h}(\mathrm{n}=10)$.

SK-BR-3 was slightly reduced after 5 days of treatment (Fig. 4a). The apoptotic rate of the breast cancer cells was not affected by E2. Treatment with E2 and adiponectin in high physiological concentrations $(15 \mu \mathrm{g} / \mathrm{ml})$ significantly increased the apoptotic rate of MDA-MB-231 cells and there was a trend towards a higher apoptotic rate of MCF-7 and SK-BR-3 cells, respectively (Fig. 4b).

To further examine the molecular mechanisms underlying these observations, we investigated the effect of E2 combined with adiponectin on the expression of $\mathrm{ER} \alpha$, the cell cycle genes cyclin A2 and D1 and the apoptosis gene Fas-L in MCF-7 cells. Neither E2 alone nor the combination of E2 and adiponectin had an effect on the expression of ER $\alpha$ (Fig. 3b) or the proapoptotic gene FAS-L (data not shown). In contrast, the transcript levels of cyclin A2 and D1 were significantly increased by E2 in the MCF-7 cells. Co-treatment with adiponectin inhibited this E2-triggered increase of the cyclin A2 expression, but had no effect on the cyclin D1 mRNA levels (Fig. 3b).

\section{Discussion}

The relationship between obesity and breast cancer risk is well known. Mantzoros et al, as well as others, have demonstrated that low adiponectin serum levels are associated with increased breast cancer risk and this relationship is independent of BMI
(20). Miyoshi et al reported that adiponectin levels are inversely related to the clinicopathological characteristics of breast cancer, meaning that an aggressive phenotype exemplified by a large tumor size and high histological grade is more likely to occur with low adiponectin (19). These observations suggest that adiponectin directly or indirectly affects breast cancer development.

In the current study AdipoR1 mRNA was detected in the MCF-7, SK-BR-3 and MDA-MB-231 breast cancer cells and AdipoR1 protein in the MCF-7 and SK-BR-3 cells whereas AdipoR1 protein is low or not expressed in the MDA-MB-231 cell line. AdipoR2 mRNA was only amplified from the MCF-7 and MDA-MB-231 cells. These findings are only partly in agreement with the data reported by Takahata et al who detected both receptors in all of these cell lines (32).

Due to the clear clinical inverse correlation between adiponectin and breast cancer, we expected antiproliferative and/or apoptotic effects of adiponectin on the human breast cancer cells in vitro. Tworoger et al showed that the menopausal status influences the association between breast cancer and serum adiponectin levels (31). To our knowledge, our study is the first to demonstrate the estrogen-dependent antiproliferative and apoptotic effects of adiponectin. We did not observe any effects of adiponectin on the growth or apoptosis of breast cancer cells cultured in steroid-hormonefree medium, not even when adiponectin was used at 
a)

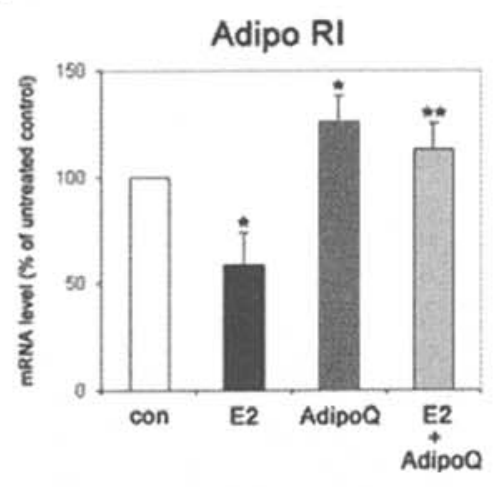

b)
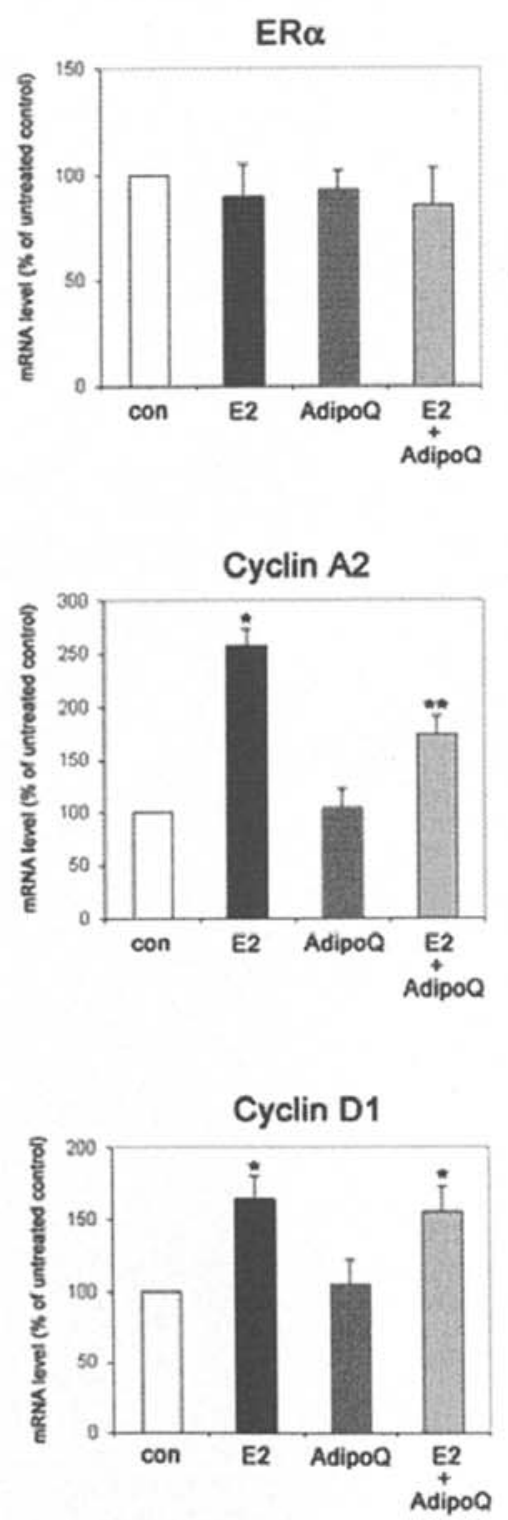

Figure 3. The effects of $17-\beta$ estradiol and adiponectin on gene expression in MCF-7 cells. Cells were treated with 17- $\beta$ estradiol (E2) alone or in combination with $15 \mu \mathrm{g} / \mathrm{ml}$ adiponectin for $24 \mathrm{~h}$. Isolated mRNA was analyzed by real-time RT-PCR. Data are expressed as a percentage of the untreated medium control ( $n=4)$. (a) mRNA levels of AdipoR1. (b) mRNA levels of $\mathrm{ER} \alpha$, cyclin $\mathrm{A} 2$ and $\mathrm{D} 1$; ${ }^{*} \mathrm{p}<0.01$ vs. untreated control, ${ }^{* *} \mathrm{p}<0.01$ vs. E2. a)



MDA-MB-231

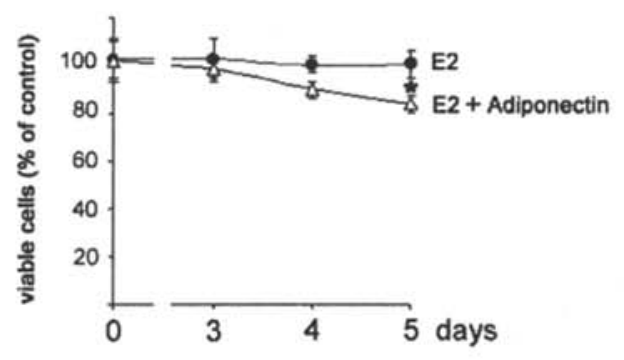

\section{SK-BR-3}

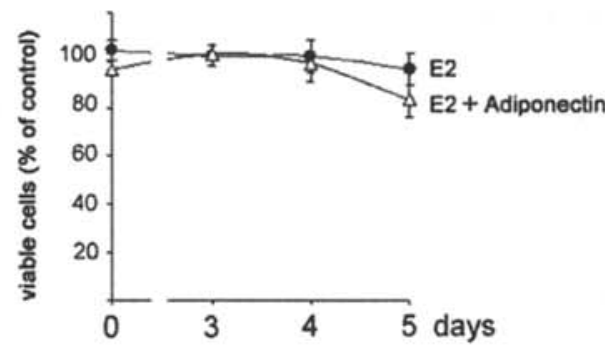

b)

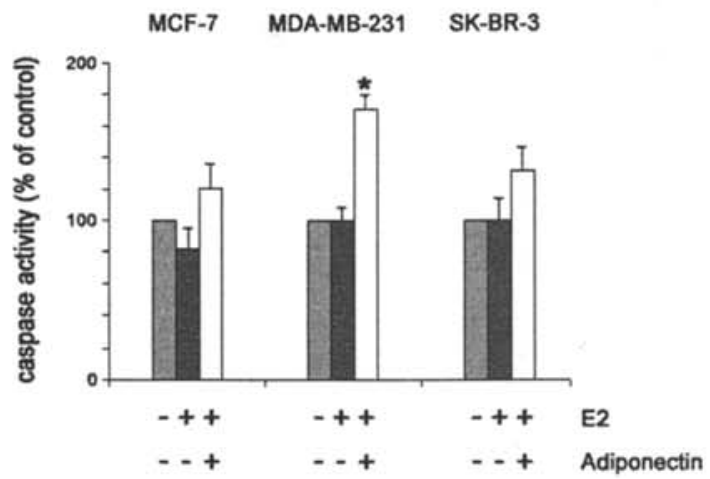

Figure 4. The effects of adiponectin on the growth and apoptosis of breast cancer cells in the presence of 17-B estradiol. (a) Cells were treated with E2 alone $(3 \mathrm{nM})$ or in combination with $15 \mu \mathrm{g} / \mathrm{ml}$ adiponectin for up to 5 days and the relative cell numbers were assessed by means of a CTB assay as described in Materials and methods. (b) Cells were treated with E2 alone or in combination with $15 \mu \mathrm{g} / \mathrm{ml}$ adiponectin for $6 \mathrm{~h}$ and the caspase 3 and 7 activation was determined. Data are expressed as a percentage of the untreated control $(n=3) ;{ }^{*} p<0.05$ vs. E2. 
supraphysiological concentrations. Previously, by not addressing possible interactions between E2 and adiponectin and thereby using undefined serum-containing culture conditions, adiponectin effects on breast cancer cell growth were reported. Arditi et al observed the antiproliferative effects of adiponectin on the MCF-7 breast cancer cells (28). Diudonne et al also reported antiproliferative effects on the breast cancer cells and observed an increase in apoptosis of up to $35 \%$ after treatment with adiponectin (24). In contrast, Kang et al did not observe a decreased proliferation of the MCF-7 cells after adiponectin treatment (30), supporting our results. Wang et al found a decreased proliferation of the MDA-MB-231 breast cancer cells after adiponectin treatment (29) and Körner et al were able to show such effects in T47D cells (33). Minimal differences in the investigational settings seem to influence the action of adiponectin in vitro. Bearing in mind these case control studies, which demonstrated that the adiponectin level of the cases was between $10-12 \mu \mathrm{g} / \mathrm{ml}$ and that of the controls between $15-18 \mu \mathrm{g} / \mathrm{ml}$, it seems important to respect these small differences in in vitro experiments. Körner et al observed an antiproliferative effect of adiponectin on the T47D breast cancer cells, which could not be shown by Wang et al, who used the same full-length recombinant adiponectin in nearly the same concentration. This difference could be explained by the different FCS concentrations used in the two studies.

In the only prospective study published so far, Tworoger et al showed an influence of menopausal status on the association between adiponectin and breast cancer risk (31). They found an increased risk of breast cancer in premenopausal women with higher adiponectin levels, but an inverse association between adiponectin levels and breast cancer risk for postmenopausal women. This, with respect to the data of Mantzoros et al, who showed a significant inverse association of breast cancer risk in post- but not premenopausal women, led us to the hypothesis that there might be an interaction of adiponectin with estrogen signaling pathways.

To our knowledge, we are the first to demonstrate that E2 significantly reduces the AdipoR1 expression in ER $\alpha$-positive MCF-7 breast cancer cells. It is tempting to speculate that the E2-triggered down-regulation of AdipoR1 may be a signaling cross-talk directly affecting breast cancer risk (32). Even though we were unable to show an effect of adiponectin on breast cancer cells alone, we demonstrated that adiponectin significantly reduced the proliferation of MDA-MB231 breast cancer cells in an E2-enriched medium. In contrast to this, adiponectin further increased the proliferation of ER-positive MCF-7 cells. The combination of E2 and adiponectin increased the apoptotic rate in all three cancer cell lines. These divergent effects are difficult to explain. E2 effects in ER $\alpha$-negative but ERß-positive MDA-MB-231 and SK-BR-3 breast cancer cells are mediated via ERß, which is discussed as a tumor suppressor (34). Therefore, the combination of adiponectin and E2 may overcome a kind of threshold and reduce proliferation and increase the apoptotic rate in those cells. Currently we are not able to explain why adiponectin even augments the E2induced proliferation rate of the ER $\alpha / E R ß$-positive MCF-7 cells. Diudonne et al reported that lower adiponectin concentrations were able to reverse the E2-induced proliferation of the MCF-7 cells completely (24). Diudonne et al further reported that the E2-induced increase of the cyclin D1 expression in MCF-7 cells was inhibited by adiponectin treatment. We did not see such effects in our experiments. E2 increased the expression of cyclin D1 in the MCF-7 cells, but despite addiing adiponectin, it was unable to reverse this effect. In contrast, adiponectin significantly decreased the E2-induced increase of cyclin A2, another cell cycle gene. We suggest that this effect on gene expression does not influence proliferation, because the combination of adiponectin and E2 actually increased proliferation of the MCF-7 cells. On the other hand, we observed an elevated apoptotic rate under the E2 and adiponectin stimuli, but we could not demonstrate a significant change in the FAS-L expression. It seems that other genes, which were not investigated in our experiments, reflect the effects of adiponectin and E2 on breast cancer cells more accurately.

In the present study we reported the estrogen-triggered reduction of AdipoR1 transcript levels in ER $\alpha / E R \beta$ positive MCF-7 cells. Our observation that treatment with adiponectin only affects the growth or apoptosis of breast cancer cells in the presence of estrogen, suggests signaling cross-talk between the estradiol and adiponectin pathways affecting the action of this adipocytokine on human breast cancer cells.

\section{Acknowledgements}

This study was funded by an intramural research grant, the ReForM C 'Metabolic effects on the development of chronic diseases in sex-hormone sensitive organs' of the University Hospital Regensburg. We thank Helena Houlihan and Angelika Vollmer for their expert technical assistance.

\section{References}

1. Morimoto LM, White E, Chen Z, Chlebowski RT, Hays J, Kuller L, Lopez AM, Manson J, Margolis KL, Muti PC, Stefanick ML and McTiernan A: Obesity, body size and risk of postmenopausal breast cancer: the Women's Health Initiative (United States). Cancer Causes Control 13: 741-751, 2002.

2. Hirose K, Tajima K, Hamajima N, Takezaki T, Inoue M, Kuroishi T, Miura S and Tokudome S: Association of family history and other risk factors with breast cancer risk among Japanese premenopausal and postmenopausal women. Cancer Causes Control 12: 349-358, 2001

3. Edman CD, Aiman EJ, Porter JC and MacDonald PC: Identification of the estrogen product of extraglandular aromatization of plasma androstenedione. Am J Obstet Gynecol 130: 439-447, 1978.

4. Moore JW, Clark GM, Bulbrook RD, Hayward JL, Murai JT, Hammond GL and Siiteri PK: Serum concentrations of total and non-protein-bound oestradiol in patients with breast cancer and in normal controls. Int J Cancer 29: 17-21, 1982.

5. Hankinson SE, Willett WC, Manson JE, Colditz GA, Hunter DJ, Spiegelman D, Barbieri RL and Speizer FE: Plasma sex steroid hormone levels and risk of breast cancer in postmenopausal women. J Natl Cancer Inst 90: 1292-1299, 1998.

6. Mantzoros CS and Flier JS: Insulin resistance: the clinical spectrum. Adv Endocrinol Metab 6: 193-232, 1995.

7. Bloomgarden ZT: Obesity, hypertension and insulin resistance. Diabetes Care 25: 2088-2097, 2002.

8. Bruning PF, Bonfrer JM, van Noord PA, Hart AA, de Jong-Bakker M and Nooijen WJ: Insulin resistance and breast-cancer risk. Int J Cancer 52: 511-516, 1992.

9. Moschos SJ and Mantzoros CS: The role of the IGF system in cancer: from basic to clinical studies and clinical applications. Oncology 63: 317-332, 2002.

10. Matsuzawa Y, Funahashi $\mathrm{T}$ and Nakamura T: Molecular mechanism of metabolic syndrome $\mathrm{X}$ : contribution of adipocytokines adipocyte-derived bioactive substances. Ann NY Acad Sci 892: 146-154, 1999. 
11. Maeda K, Okubo K, Shimomura I, Funahashi T, Matsuzawa Y and Matsubara K: cDNA cloning and expression of a novel adipose specific collagen-like factor, apM1 (AdiPose most abundant gene transcript 1). Biochem Biophys Res Commun 221: 286-289, 1996.

12. Scherer PE, Williams S, Fogliano M, Baldini G and Lodish HF: A novel serum protein similar to $\mathrm{Clq}$, produced exclusively in adipocytes. J Biol Chem 270: 26746-26749, 1995.

13. Nakano Y, Tobe T, Choi-Miura NH, Mazda T and Tomita M: Isolation and characterization of GBP28, a novel gelatin-binding protein purified from human plasma. J Biochem 120: 803-812, 1996.

14. Hu E, Liang P and Spiegelman BM: AdipoQ is a novel adiposespecific gene dysregulated in obesity. J Biol Chem 271: 10697-106703, 1996.

15. Yamauchi T, Kamon J, Ito Y, Tsuchida A, Yokomizo T, Kita S, Sugiyama T, Miyagishi M, Hara K, Tsunoda M, Murakami K, Ohteki T, Uchida S, Takekawa S, Waki H, Tsuno NH, Shibata Y, Terauchi Y, Froguel P, Tobe K, Koyasu S, Taira K, Kitamura T, Shimizu T, Nagai R and Kadowaki T: Cloning of adiponectin receptors that mediate antidiabetic metabolic effects. Nature 423: 762-769, 2003. Erratum in: Nature 431: 1123, 2004.

16. Abbasi F, Chu JW, Lamendola C, McLaughlin T, Hayden J, Reaven GM and Reaven PD: Discrimination between obesity and insulin resistance in the relationship with adiponectin. Diabetes 53: 585-590, 2004.

17. Heilbronn LK, Smith SR and Ravussin E: The insulin-sensitizing role of the fat derived hormone adiponectin. Curr Pharm Des 9: 1411-1418, 2003.

18. Dal Maso L, Augustin LS, Karalis A, Talamini R, Franceschi S, Trichopoulos D, Mantzoros CS and La Vecchia C: Circulating adiponectin and endometrial cancer risk. J Clin Endocrinol Metab 89: 1160-1163, 2004

19. Miyoshi Y, Funahashi T, Kihara S, Taguchi T, Tamaki Y, Matsuzawa Y and Noguchi S: Association of serum adiponectin levels with breast cancer risk. Clin Cancer Res 9: 5699-5704, 2003.

20. Mantzoros C, Petridou E, Dessypris N, Chavelas C, Dalamaga M, Alexe DM, Papadiamantis Y, Markopoulos C, Spanos E, Chrousos G and Trichopoulos D: Adiponectin and breast cancer risk. J Clin Endocrinol Metab 89: 1102-1107, 2004.

21. Gavrila A, Chan JL, Yiannakouris N, Kontogianni M, Miller LC, Orlova $C$ and Mantzoros CS: Serum adiponectin levels are inversely associated with overall and central fat distribution but are not directly regulated by acute fasting or leptin administration in humans: cross-sectional and interventional studies. J Clin Endocrinol Metab 88: 4823-4831, 2003.

22. Yokota T, Oritani K, Takahashi I, Ishikawa J, Matsuyama A, Ouchi N, Kihara S, Funahashi T, Tenner AJ, Tomiyama Y and Matsuzawa Y: Adiponectin, a new member of the family of soluble defense collagens, negatively regulates the growth of myelomonocytic progenitors and the functions of macrophages. Blood 96: 1723-1732, 2000

23. Neumeier M, Weigert J, Schaffler A, Wehrwein G, Muller-Ladner U, Scholmerich J, Wrede C and Buechler C: Different effects of adiponectin isoforms in human monocytic cells. J Leukoc Biol 79: 803-808, 2006.
24. Dieudonne MN, Bussiere M, Dos Santos E, Leneveu MC, Giudicelli Y and Pecquery R: Adiponectin mediates antiproliferative and apoptotic responses in human MCF7 breast cancer cells. Biochem Biophys Res Commun 34: 271-279, 2006.

25. Ståhlberg A, Åman P, Ridell B, Mostad P and Kubista M: A quantitative real-time PCR method for detection of Blymphocyte monoclonality by comparison of kappa and lambda immunoglobulin light chain expression. Clin Chem 49: 51-59, 2003.

26. Livak KJ and Schmittgen TD: Analysis of relative gene expression data using real-time quantitative PCR and the 2 (-Delta Delta C(T)) method. Methods 25: 402-408, 2001.

27. Neumeier M, Weigert J, Schaffler A, Weiss T, Kirchner S, Laberer S, Scholmerich J and Buechler C: Regulation of adiponectin receptor 1 in human hepatocytes by agonists of nuclear receptors. Biochem Biophys Res Commun 334: 924-929, 2005.

28. Arditi JD, Venihaki M, Karalis KP and Chrousos GP: Antiproliferative effect of adiponectin on MCF7 breast cancer cells: a potential hormonal link between obesity and cancer. Horm Metab Res 39: 9-13, 2007.

29. Wang Y, Lam JB, Lam KS, Liu J, Lam MC, Hoo RL, Wu D, Cooper GJ and Xu A: Adiponectin modulates the glycogen synthase kinase-3beta/beta-catenin signaling pathway and attenuates mammary tumorigenesis of MDA-MB-231 cells in nude mice. Cancer Res 66: 11462-11470, 2006

30. Kang JH, Lee YY, Yu BY, Yang BS, Cho KH, Yoon DK and Roh YK: Adiponectin induces growth arrest and apoptosis of MDA-MB-231 breast cancer cell. Arch Pharm Res 28: 1263-1269, 2005.

31. Tworoger SS, Eliassen AH, Kelesidis T, Colditz GA, Willett WC, Mantzoros CS and Hankinson SE: Plasma adiponectin concentrations and risk of incident breast cancer. J Clin Endocrinol Metab 92: 1510-1516, 2007.

32. Takahata C, Miyoshi Y, Irahara N, Taguchi T, Tamaki Y and Noguchi S: Demonstration of Adiponectin Receptors 1 and 2 mRNA expression in human breast cancer cells. Cancer Lett 250: 229-236, 2007

33. Körner A, Pazaitou-Panayiotou K, Kelesidis T, Kelesidis I, Williams CJ, Kaprara A, Bullen J, Neuwirth A, Tseleni S, Mitsiades N, Kiess W and Mantzoros CS: Total and highmolecular-weight adiponectin in breast cancer: in vitro and in vivo studies. J Clin Endocrinol Metab 92: 1041-1048, 2007.

34. Skliris G, Munot K, Bell S, Carder P, Lane S, Horgan K, Lansdown M, Parkes A, Hanby A, Markham A and Speirs V: Reduced expression of oestrogen receptor beta in invasive breast cancer and its re-expression using DNA methyltransferase inhibitors in a cell line model. J Pathol 201: 213-220, 2003. 